\title{
POST-BREEDING EXTRA-PAIR PSEUDOCOPULATION IN THE PYGMY NUTHATCH
}

\author{
LISA D. WALKER-ROSEMAN, 32430 Forest Lane, Fort Bragg, California 95437; \\ feather@mcn.org \\ KEVIN A. GIUSTI, 248 South Harrison Street, Fort Bragg, California 95437; \\ nrthcsteel@sbcglobal.net
}

FLOYD E. HAYES, Department of Biology, Pacific Union College, 1 Angwin Ave., Angwin, California 94508; floyd_hayes@yahoo.com

Nonreproductive sexual behaviors such as pseudocopulation (also referred to as noncopulatory mounting and backstanding), homosexuality, and autoeroticism have been reported in more than 230 species of birds in at least 37 families (Bagemihl 1999, Balcombe 2006). The functions of nonreproductive sexual behaviors in birds are poorly understood. Such behaviors, which include reverse mounting during the breeding season (e.g., Nuechterlein and Storer 1989) and pseudocopulation outside of the breeding season (e.g., Short 1971), are often associated with courtship or pair bonding. Reverse mounting and pseudocopulation may also occur in social contexts outside of the pair bond, perhaps to maintain group dynamics by reducing aggression (e.g., MacRoberts and MacRoberts 1976, Moynihan 1990, Dawson and Mannan 1991, Hagemeyer 2016).

Nuthatches of the genus Sitta are socially monogamous, with pairs often remaining together throughout the nonbreeding season and through multiple breeding seasons (Matthysen 1998). Nevertheless, genetic studies have revealed that extrapair paternity is frequent in at least two species: the European Nuthatch (S. europaea), of which about $10 \%$ of offspring are sired by a male other than the female's social mate (Segelbacher et al. 2005), and the Brown-headed Nuthatch (S. pusilla), of which about $32-45 \%$ of offspring are so sired (Han et al. 2015). Nonreproductive sexual behavior has not been previously reported in any species of nuthatch. In this note we provide the first documentation of extra-pair pseudocopulation in the Pygmy Nuthatch.

At 09:21 on 6 September 2019, Walker and Giusti observed three Pygmy Nuthatches noisily foraging on pine nuts along the Enchanted Forest Trail that leads to the Virgin Creek Beach section of MacKerricher State Park in Fort Bragg, California $\left(39^{\circ} 28^{\prime} 26^{\prime \prime} \mathrm{N}, 123^{\circ} 47^{\prime} 59^{\prime \prime} \mathrm{W}\right)$. Their photos revealed that all three birds were adults, by the marked contrast between the brown crown and bluish gray back (juveniles are grayer with less contrast) and the absence of a yellow rictus (Norris 1958, Pyle 1997, Kingery and Ghalambor 2001). Because the Pygmy Nuthatch is a sexually monochromatic species (Pyle 1997, Kingery and Ghalambor 2001), our identification of sexes in the following behavioral descriptions is based on its known copulation behavior, in which the female initiates copulation, then the male mounts the female (Kingery and Ghalambor 2001).

A presumed female hunkered down on a branch, made an unfamiliar highpitched call resembling that of a begging juvenile, quivered her wings, and was quickly approached by two presumed males. After each male took turns mounting the female in rapid succession, Giusti obtained a 16-second sequence of photographs illustrating each male mounting the female a second time (Figure 1). The three nuthatches were briefly together (Figure 1A). Male A, which held a seed in its beak, mounted the female while male $B$, which lacked a seed in its beak, perched about $0.5 \mathrm{~m}$ away (Figure 1B-C). A few seconds later, male A dismounted the female and male $\mathrm{B}$ approached the pair, with all three birds within a few centimeters of each other (Figure 1D-E). A few seconds later, male A departed and male B mounted the 


\section{NOTES}

female (Figure 1F). The female did not struggle when mounted and appeared cooperative with both males. We could not determine whether cloacal contact occurred. We observed no aggression between the two males. The trio flew away immediately after the second round of mounting.

In coastal California, egg dates for the nominate race of the Pygmy Nuthatch range from 20 April to 17 June (Norris 1958, Kingery and Ghalambor 2001). Because our observation of mounting by the trio of nuthatches occurred in early September, well after the normal breeding season, mounting by the trio was almost certainly nonreproductive and should be regarded as pseudocopulation.

The Pygmy Nuthatch is a cooperatively breeding species in which breeding pairs are often joined by up to three nonbreeding helpers, usually yearling males related

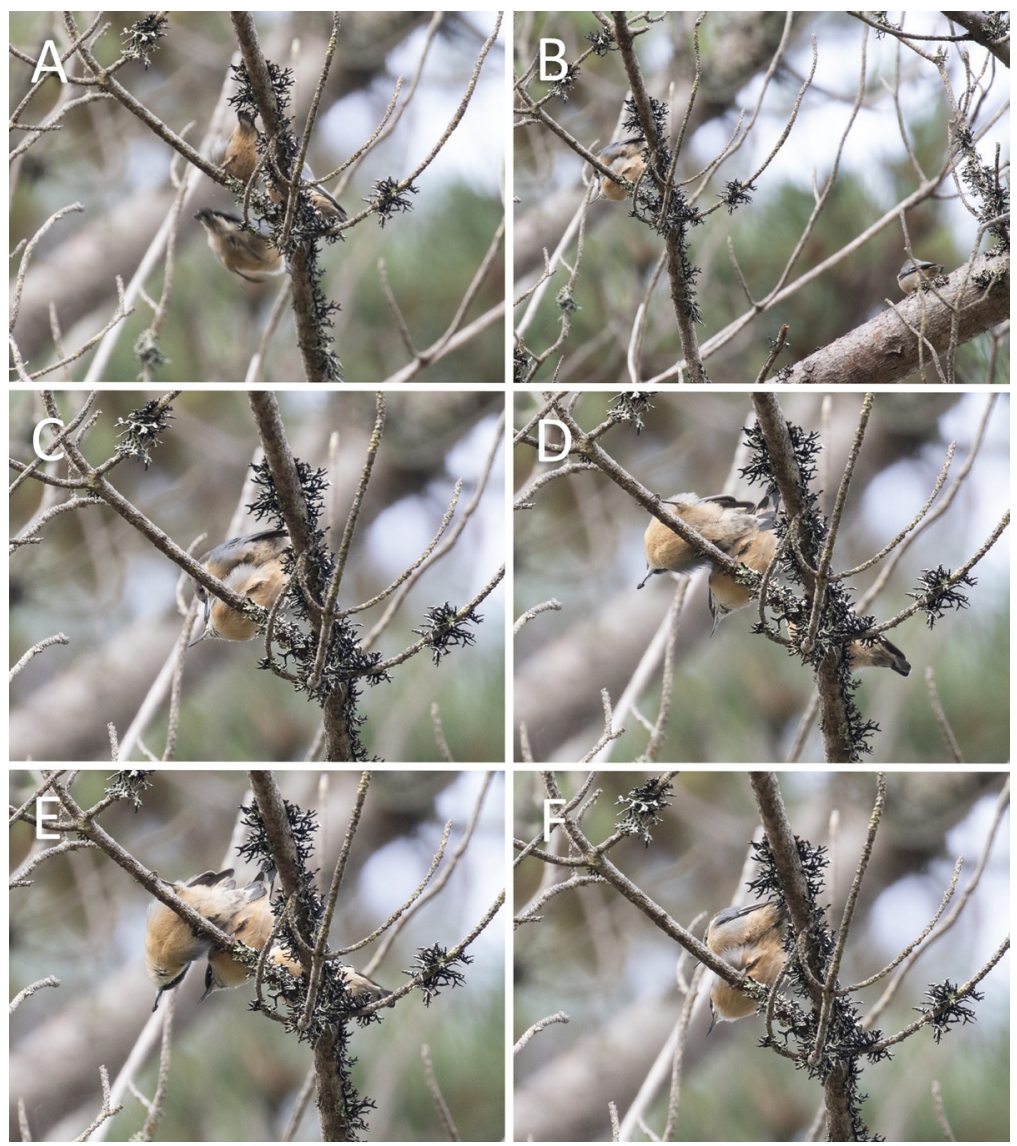

Figure 1. Sequence of a presumed female Pygmy Nuthatch mounted by two presumed males: $(\mathrm{A})$ the trio together; $(\mathrm{B}, \mathrm{C})$ male $\mathrm{A}$ mounts while male $\mathrm{B}$ is perched nearby; $(\mathrm{D}, \mathrm{E})$ male A dismounts while male $\mathrm{B}$ approaches; and $(\mathrm{F})$ male $\mathrm{B}$ mounts after male A flies away. 


\section{NOTES}

to the breeding pair (Norris 1958, Sydeman et al. 1988). Several lines of evidence suggest that the helpers do not contribute genetically to the offspring (Sydeman et al. 1988). However, the genetic relationships among mated parents, helpers, and offspring in the Pygmy Nuthatch have never been studied. The social and genetic relationships among the trio we observed are unknown, so it is uncertain whether the trio consisted of a mated pair and a male helper.

The function of the pseudocopulation that we observed in the Pygmy Nuthatch is unknown. It may strengthen the bond or reduce aggression among a cooperatively breeding trio or among individuals of a larger flock. Research with banded individuals of known genetic relationships would better document the full repertoire of sexual behaviors and clarify their functions in the Pygmy Nuthatch.

\section{LITERATURE CITED}

Bagemihl, B. 1999. Biological Exuberance: Animal Homosexuality and Natural Diversity. St. Martin's Press, New York.

Balcombe, J. 2006. Pleasurable Kingdom. Macmillan, London.

Dawson, J. W., and Mannan, R. W. 1991. The role of territoriality in the social organization of Harris' Hawks. Auk 108:649-660; doi.org/10.2307/4088105.

Hagemeyer, N. 2016. Sex-obsessed or just sociable? Non-copulatory displays in the Hamerkop. Front. Ecol. Environ. 14:397-398; doi.org/10.1002/fee.1318.

Han, K-L., Cox, J. A., and Kimball, R. T. 2015. Uncommon levels of relatedness and parentage in a cooperatively breeding bird, the Brown-headed Nuthatch (Sitta pusilla). Wilson J. Ornithol. 127:593-600; doi 10.1676/14-193.1.

Kingery, H. E., and Ghalambor, C. K. 2001. Pygmy Nuthatch (Sitta pygmaea), in The Birds of North America (A. F. Poole and F. B. Gill, eds.), no. 567. Acad. Nat. Sci., Philadelphia; doi.org/10.2173/bna.567.

MacRoberts, M. H., and MacRoberts, B. R. 1976. Social organization and behavior of the Acorn Woodpecker in central coastal California. Ornithol. Monogr. 21:1-115; doi.org/10.2307/40166738.

Matthysen, E. 1998. The Nuthatches. Poyser, London.

Moynihan, M. 1990. Social, sexual, and pseudosexual behavior of the Blue-bellied Roller, Coracias cyanogaster: The consequences of crowding or concentration. Smithson. Contr. Zool. 491:1-23; doi.org/10.5479/si.00810282.491.

Norris, R. A. 1958. Comparative biosystematics and life history of the nuthatches Sitta pygmaea and Sitta pusilla. Univ. Calif. Publ. Zool. 56:119-300.

Nuechterlein, G. L., and Storer, R. W. 1989. Reverse mounting in grebes. Condor 91:341-346; doi.org/10.2307/1368312.

Pyle, P. 1997. Identification Guide to North American Birds, part I, Columbidae to Ploceidae. Slate Creek Press, Bolinas, CA.

Segelbacher, G., Kabisch, D., Stauss, M., and Tomiuk, J. 2005. Extra-pair young despite strong pair bonds in the European Nuthatch (Sitta europaea). J. Ornithol. 146:99-102; doi.org/10.1007/s10336-004-0062-5.

Short, L. L. 1971. Systematics and behavior of some North American woodpeckers, genus Picoides (Aves). Bull. Am. Mus. Nat. Hist. 145:1-118.

Sydeman, W. J., Güntert, M., and Balda, R. P. 1988. Annual reproductive yield in the cooperative Pygmy Nuthatch (Sitta pygmaea). Auk 105:70-77; doi.org/10.1093/ auk/105.1.70. 